\title{
Flipped learning design in EFL classrooms: implementing self-regulated learning strategies to develop language skills
}

\author{
Mücahit Öztürk ${ }^{1}$ and Ünal Çakıroğlu ${ }^{2^{*}}$ (D
}

* Correspondence: cakiroglu@
trabzon.edu.tr; unalts@hotmail.com
²Department of Computer
Education and Instructional
Technology, Fatih Faculty of
Education, Trabzon University,
Söğütlü, Akçaabat, 61335 Trabzon,
Turkey
Full list of author information is
available at the end of the article

\section{Springer Open}

\begin{abstract}
This study examined the development of students' language skills in a flipped English foreign language course designed with self-regulated learning strategies. The study was conducted with a quasi-experimental design. While the experimental group received the course through flipped classroom model designed with self-regulated learning strategies, control group did not use self-regulated learning strategies in the flipped classroom model. The results indicated that self-regulated learning strategies positively affected the development of foreign language skills in the flipped classroom model. A significant difference in favor of the group working with the platform including selfregulated learning strategies outperformed in speaking, reading, writing, and grammar test scores. However, no significant difference in the listening test results was found.
\end{abstract}

Keywords: Flipped classroom, Self-regulated learning strategies, EFL course

\section{Introduction}

With the advances in online learning, flipped classroom model (FCM) has increased in popularity as innovative learning practices for supporting higher education. As a new norm of blended learning, the FCM reverses traditional teaching, and reorganizes the teaching time to provide more class time for students to learn. Researchers documented that FCM offers opportunities to study with rich course contents, at their own pace, providing a flexible learning environment with technology support (Shih \& Huang, 2020). While students are preparing for the lesson with the materials out of class, they can do hands-on activities in the in-class sessions (Bergmann \& Sams, 2012). In the FCM, during out-of class sessions, students can participate in online discussions while learning about course content by watching videos (Hosseini, Ejtehadi, \& Hosseini, 2020; Leatherman \& Cleveland, 2020). In this period, learning management systems, YouTube, blogs, wikis or etc. are used to understand the given content. Educators also offer specialized online learning platforms (Wanner \& Palmer, 2015). In the in-class sessions, students are able to practice what they have learned at out-of class sessions within collaborative group working, problem solving, discussing, and working on projects (Huang \& Hong, 2016) with instructors' feedback and guidance. Instructor

(c) The Author(s). 2021 Open Access This article is licensed under a Creative Commons Attribution 4.0 International License, which permits use, sharing, adaptation, distribution and reproduction in any medium or format, as long as you give appropriate credit to the original author(s) and the source, provide a link to the Creative Commons licence, and indicate if changes were made. The images or other third party material in this article are included in the article's Creative Commons licence, unless indicated otherwise in a credit line to the material. If material is not included in the article's Creative Commons licence and your intended use is not permitted by statutory regulation or exceeds the permitted use, you will need to obtain permission directly from the copyright holder. To view a copy of this licence, visit http://creativecommons.org/licenses/by/4.0/. 
customizes discussions and facilitates interactions to help students acquire meaningful learning through in-class activities. In the FCM process, it is important for students to study with online contents before active participation in the in-class sessions (Amiryousefi, 2019). Thus, students in the flipped classrooms should take their own learning responsibilities, in out-of-class sessions prior to their in-class sessions ( $\mathrm{Ng}, 2018)$. In line with this, they are recommended to have highly developed self-regulated learning skills in the FCM (Rasheed et al., 2020).

FCM has been increasingly studied in many disciplines and a growing body of research indicated that the FCM has positively affected students' learning performances (Çakıroğlu \& Öztürk, 2017; Liu, Sands-Meyer, \& Audran, 2019). In addition, Kostaris, Sergis, Sampson, Giannakos, and Pelliccione (2017) revealed that FCM contributed positively to students' cognitive learning outcomes, motivation and engagement in the information and communication course. In contrast, Cabı (2018) did not find a significant contribution to students' academic success in the flipped computer science course compared to traditional teaching methods. The results showed that students have difficulties in learning on their own at home, time constraints and students are getting bored quickly. In a more recent study,Al-Samarraie, Shamsuddin, \& Alzahrani, 2019 reviewed 85 articles on FCM and found that academic achievement, motivation, attitude, metacognition, satisfaction, self-regulated learning, self-efficacy draw attention as variables researched in FCM. The results suggested that FCM has the potential to contribute to learning outcomes in different disciplines. The study noted that, in FCM studies, there were problems such as lack of instant feedback, course structure, selfdiscipline, length of videos and time constraint. For future studies, it was suggested that students should be prepared for the lesson outside the classroom and they need to be supported by various ways to increase their motivation and self-regulation.

For an English as a foreign language classroom (EFL) with an ultimate goal of language learning through communication, the FCM can allow more time for students to learn English during in-class and out-of-class activities, FCM has the potential to address the constraints of teaching EFL course (Lee \& Wallace, 2018). In the EFL context, studies generally focused on attitudes and perceptions or effects of various implementations of FCM (Adnan, 2017; Chen Hsieh et al., 2017, b; Chuang, Weng, \& Chen, 2018). Many studies on FCM put the emphasis to compare the overall effectiveness of the FCM against the traditional presentations. Studies offer to engage learners in the learning process by providing self-regulated strategies, however, only few studies have investigated how FCM could be used to empower students' SRL skills. In accordance with this, it is still scarce to address how to integrate these strategies in the FCM learning process in EFL courses. Accordingly, this study investigated the effect of providing selfregulated learning strategies on students' academic performance in the flipped EFL course, by offering solutions to the problems expressed in FCM studies such as the inability of students to take responsibility for learning, the length of the videos, and the lack of immediate feedback.

\section{Flipped classroom model in English as foreign language (EFL) course}

Although some innovative teaching techniques are being applied in EFL courses, traditional EFL teaching methods still dominate (Chen Hsieh, Wu, \& Marek, 2017). For 
example, in the grammar translation method, students examine the grammatical structure of the language and study with the sentence structure and word lists of the language. Considering the traditional techniques such as audio-lingual, direct, communicative methods used in the EFL teaching, it is argued that instructors do not have opportunity to provide collaborative and interactive activities (Egbert, Herman, \& Lee, 2015). While the instructor spends most of the course time presenting the content, students generally take notes as passive listeners, which often leads them to have low motivation (Huang \& Hong, 2016). One way of EFL teaching is teaching through communication. At this point, FCM can lead to more intercommunication for EFL course to provide the learners immediate corrective feedback by instructors when learners are assimilating the new information and developing their insights (Hosseini et al., 2020). Egbert et al. (2015) suggest that FCM can help overcome the lack of communication in language teaching. Students can watch online videos in the out-of-class sessions, allowing them to study on grammar principles and speaking techniques. In FCM, students can perform listening activities with audio files, engage in writing activities with discussion forums or they can work collaboratively on the projects (Wu, Hsieh, \& Yang, 2017). Under the guidance of the instructors, feedback can be given, knowledge exchange or remedial support can be provided for students' meaningful learning during in-class activities (Liu et al., 2019). Taking advantage of the FCM, students may participate in writing activities and improve their speaking skills through discussion forums and chat rooms. In addition, FCM can make it easier for students to learn grammar rules and structures by providing them with access to different learning resources (Evseeva \& Solozhenko, 2015). Taking the advantages of FCM for teaching EFL, (Lin and Hwang, 2018) also conducted a study aiming at improving EFL students' English oral presentation in FCM in a Taiwanese university.

FCM shifts the responsibility of learning from the instructors to the students and directs students to be active in the activities. The fact that students take responsibility for learning, planning, monitoring and evaluating their own learning process is generally discussed in self-regulated learning (SRL) (Lai \& Hwang, 2016). In FCM, owing to their lack of SRL, students might fail to manage the instructional materials, time, help or their study (Rasheed et al., 2020). Students sometimes cannot organize their time to watch the videos and address the basic knowledge for the in-class activities (Zheng, Ward, \& Stanulis, 2020). In the out-of-class activities, FCM requires some extent of guidance in solving problems (Rahman, Aris, Mohamed, \& Zaid, 2014). In this sense, the innovative EFL teaching methods suggest using video, audio, picture, presentation files or concept maps which are naturally all formats of materials studied in FCM to make students more active (Egbert et al., 2015). Collaborative group work, discussions, feedback and problem solving activities of FCM are also related to taking the responsibility of learning that is in accord with the suggested EFL teaching methods. (Turan and Akdag-Cimen, 2020) reviewed the studies done in the flipped EFL course and highlighted that FCM mostly contributes positively to the development of EFL skills. In future studies, they suggested to investigate the effect of the flipped EFL class on learners' grammar knowledge, listening skills, and reading skills. In this context, Zou (2020) argued that both FCM and innovative EFL teaching methods are studentcentered, therefore innovative ways should be applied to enact students' self-regulated learning in the flipped EFL course. 


\section{Self-regulated learning strategies in flipped classroom model}

Self-regulated learning (SRL) is meta-cognitive, motivational and behavioral involvement of students in their own learning process (Zimmerman, 1990). Students can actively control the learning process by using SRL strategies such as planning learning activities, self-motivation, organizing, repeating, self-monitoring, and evaluating their own learning (Artino \& Stephens, 2009). Generally, SRL is addressed as a cyclical process consisting of three phases (Zimmerman, 1998). Figure 1 summarizes the stages in SRL development process.

Forethought Phase: Students analyze the learning task and determine its purpose to complete the task.

\section{Performance phase}

Students use strategies to keep their motivation high and to complete the learning tasks. When the tasks are difficult to achieve or students are less experienced with the suggested strategy, they sometimes fail or be reluctant to use the new strategies. They may need feedback while working on the tasks.

\section{Self-reflection phase}

In this phase, students assess their performances in the learning tasks and their feelings about the strategies they used.

FCM provides the opportunity to create interactive environments during in-class sessions, and supports individual learning in out-of-class sessions (Blau \& Shamir-Inbal, 2017). Wang (2019) revealed that in FCM, students' SRL awareness predicts academic success and can affect online behaviors. Zou, Luo, Xie, and Hwang (2020) examined the studies on flipped language classes and revealed that FCM increases the academic achievements and motivations of students and improves self-regulated learning. In this sense, some strategies are suggested to support students' SRL to gain positive learning outcomes (Ferreira, Simão, \& da Silva, 2017). With SRL strategies, students can

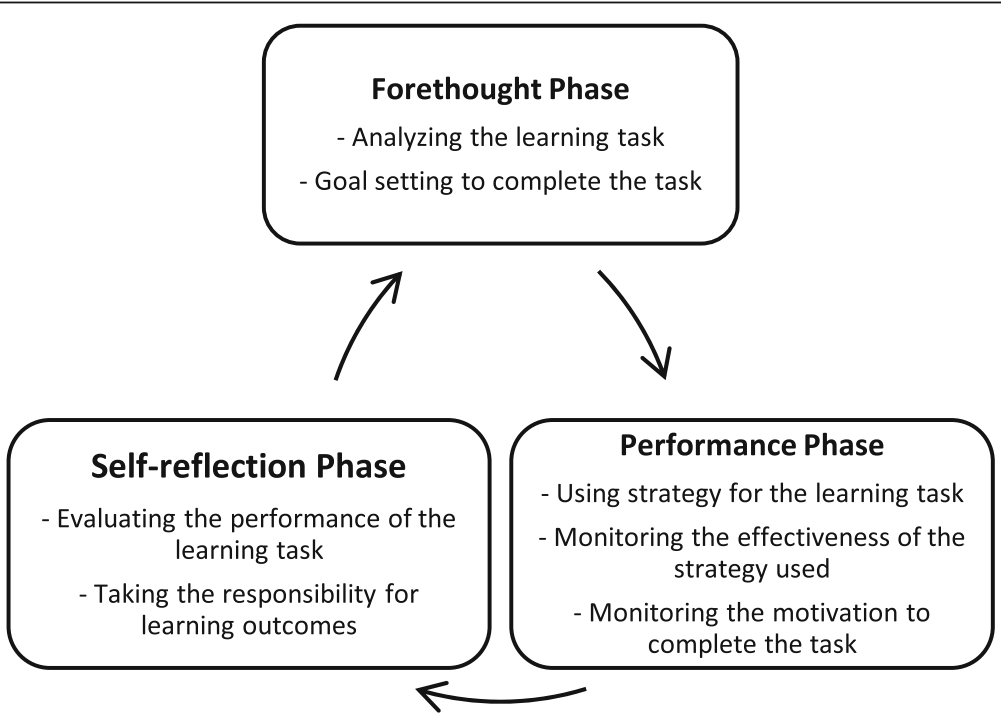

Fig. 1 Self-regulated learning phases (Adapted from Zumbrunn, Tadlock, \& Roberts, 2011) 
monitor and regulate their studies and feelings to be in a better learning position. According to Lai and Hwang (2016), integrating SRL strategy into flipped learning can provide better learning outcomes by improving students' self-efficacy as well as planning and using study time effectively. Online tests or similar tools may motivate students and provide positive attitudes and high academic achievements (Sun, Xie, \& Anderman, 2018; Wang, 2017). They should manage the time in out-of-class activities and also continue in-class activities. Students can seek help from peers, instructors or other sources while working in FCM. In out-of-class activities, they should receive and benefit from instructor feedback somewhat differently from face-to-face environments (Williamson, 2015). van Alten, Phielix, Janssen, and Kester (2020) suggested videos supported by SRL in the course conducted with FCM and revealed that SRL support has positive contributions to learning outcomes in FCM. In this context, SRL instructions were given to students before and after watching the videos in order to benefit from planning, time management and metacognition strategies. However, in the study some students were not satisfied with the support of SRL and it was suggested that this situation should be taken into account in future studies.

\section{Purpose of the study}

Previous research in FCM has shown that students' success in the courses is in relation with their SRL. Thus, it becomes important to suggest innovative solutions for improving SRL in both in and out-of-class sessions of FCM. In flipped EFL classroom, it is difficult for students to manage how and when they should study or how to evaluate their learning in in-class and out-of-class activities. In this line of reasoning, taking responsibilities in or out-of school activities is a challenging issue for students in EFL classes. Thus, EFL instructors should benefit more from SRL strategies in the FCM and a model associating the SRL strategies and EFL sub-skills is required to guide them. Hence, both out-of-class and in-class sessions of the FCM should be revised in terms of supporting SRL strategies. Although previous research has investigated the use of FCM in EFL courses, the conditions under which SRL strategies foster the EFL skills (in terms of reading, writing, speaking, listening) still remain unclear. Thus, a need exists for more research in order to better understand the roles of SRL strategies in FCM-based EFL instruction. Revisiting SRL strategies in FCM, we suggested a model to develop EFL skills in FCM settings and we tested the model on the EFL academic performances. Accordingly, the current experimental study seeks to answer how using self-regulated learning strategies in the flipped EFL is effective on students' learning of EFL skills.

\section{Method}

To evaluate the effectiveness of the SRL strategies in FCM, this study was conducted as a quasi-experimental pretest-posttest control group design by assigning the participants into an experimental group and a control group. We designed FCM_SRL system for the flipped EFL course with SRL strategies, and FCM_WEB for the flipped EFL course without SRL strategies. While the experimental group (EG) students studied with FCM_SRL, the control group (CG) students studied in FCM_WEB. In the research conditions, we manipulated the instructional strategies used in online sessions of the 
FCM-based instruction. In addition, we measured the impact of the research conditions on the following student variables: reading, writing, listening and grammar use skills. The students in EG and CG received the same learning activities in which SRL strategies were taken as independent variables of the experimental study.

\section{Participants}

Participants enrolled in English course as foreign language at a state university accounting department in Turkey. The students (CG $(n=24)$, EG $(n=25)$; age range $18-20)$ were randomly classified into experimental and control groups. They were pre-tested at the beginning of the intervention and found to have a beginner level of English. In EG, only two students got the pretest score 30-40, all others got less than 30. Also, in CG, only one student got the pretest score of 35 , and all others got less than 30 .

\section{Research design}

In order to integrate SRL strategies into the FCM, we considered the Zimmerman (1998) model as a basis, and we designed new tools for students in order to support them to exhibit SRL strategies during FCM instruction. The suggested model is depicted in Fig. 2.

\section{The suggested SRL based FCM model}

In the model, Forethought phase of SRL is completed with out-of-class activities. In this phase, students set the course goals, plan and prepare for the in-class activities. In performance and self-reflection phases, students work on assigned tasks during in-class sessions and they can monitor their learning process and evaluate their own performances.

Using SRL strategies such as goal setting, self-efficacy, help seeking, organizing, rehearsing, time management, feedback and self-evaluation positively contributes to EFL learning (Roohani \& Asiabani, 2015). Goal setting strategy reflects students' goals and

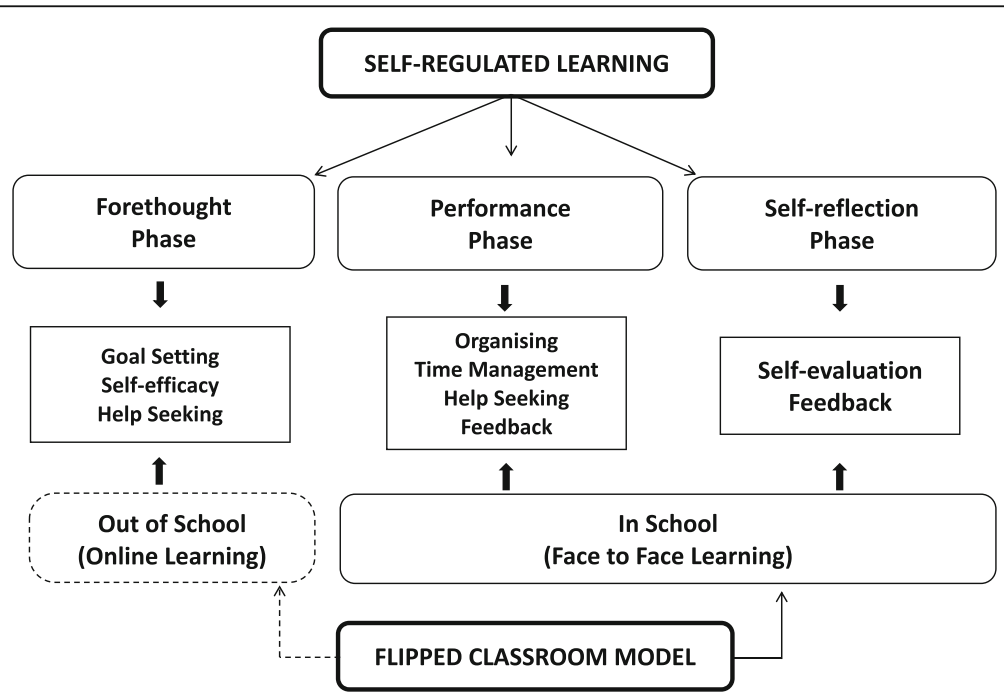

Fig. 2 Self-regulated learning within flipped classroom model 
plans for meaningful learning. Self-efficacy strategy is a belief that the student can successfully complete the assigned task realizing the adequacy of a subject (Morshedian, Hemmati, \& Sotoudehnama, 2017). Help seeking strategy is for the students to get support from the instructor or peers upon need in the learning process. Organizing strategy is about organizing course materials to facilitate students' own learning. Rehearsing is another strategy that the student struggles and repeats to learn a topic permanently (Zimmerman, 2008). Time management strategy is organizing the time to finish the given task on time (Panadero \& Alonso-Tapia, 2014). Self-evaluation strategy is about the assessment of the student's own learning processes. Overall, when implementing FCM, one can consider that basically the performance and self-reflection phases are provided during in-class activities and the forethought phase is exhibited during out-ofclass activities.

In the first week of the 13-week study, FCM_SRL and FCM_WEB were introduced to study groups. Then, in the second week, students were pre-tested to determine their English proficiency. While FCM_SRL includes the modules for SRL strategies (diary module, forum module and reporting module), FCM_WEB does not. The same online contents (Course module, Test module) were used in the EG and the CG. Students were able to follow their performances online. The same activities were performed in both groups during the in-class sessions. However, EG students studied with the worksheet and various SRL strategies were used.

For 10 weeks, basic EFL topics were delivered considering the schedule presented in Table 1.

At the last week of the study, students were given a post-test (grammar, listening, reading, speaking, and writing) to compare their achievement scores. The instructional process in two groups was presented in Fig. 3.

The FCM provides multiple opportunities for students to interact with materials and peers in-class so that they learn actively rather than passively as in a teacher-centered approach. The instructor in this study regularly followed the online activities of the students in the out-of-class sessions. In addition, he encouraged students to complete their tasks by sharing their online activity reports before the in-class sessions. The instructor carefully monitored the students in two groups and reminded students about their work and guided them to work with online tasks in out-of-class and in-class activities. The instructor encouraged students to complete their tasks by sharing their online activity reports before the in-class sessions. Therefore, no serious problems were encountered with student participation throughout the study. Thus, various strategies were used to encourage students to engage all activities in two groups.

Table 1 EFL course topics

\begin{tabular}{ll}
\hline Weeks & Topic \\
\hline Week 2-3-4 & Simple Present Tense \\
Week 5-6-7 & Simple Past Tense \\
Week 8 & Review of previous lessons \\
Week 9 & Future Tense \\
Week 10-12 & Review of previous lessons \\
\hline
\end{tabular}



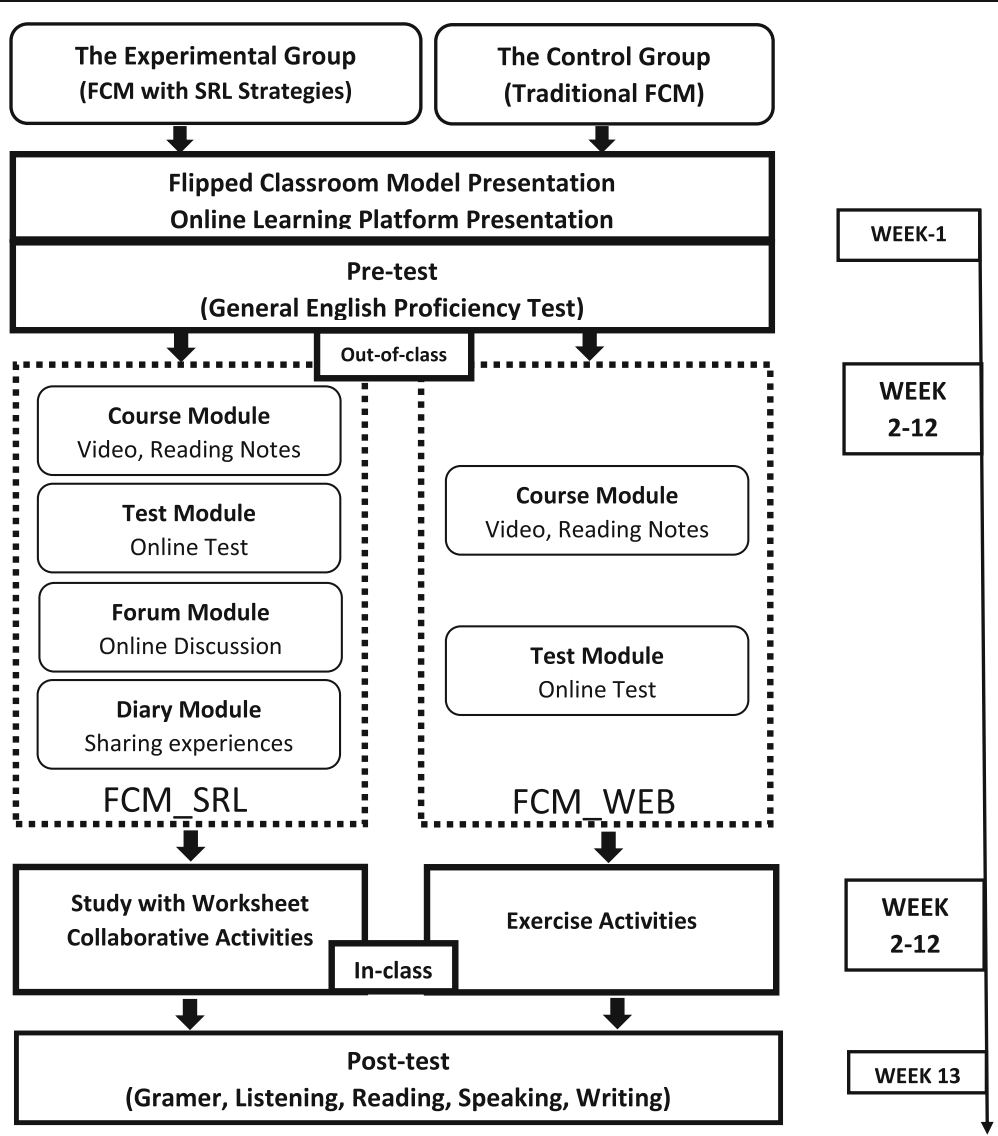

Fig. 3 Procedure followed in experimental and control groups

\section{Activities in experimental group}

Students in EG got prepared for in-class sessions with FCM_SRL integrated with SRL strategies. These strategies were embedded in course, test, forum and diary modules. SRL strategies for forethought phase consist of setting goals, planning, help seeking and testing the performances (Cho, 2004; Zimmerman, 2008; Zumbrunn et al., 2011). The SRL strategies in FCM_SRL are shown in Fig. 4.

In FCM_SRL, after watching the videos, students used test module weekly to test their performances. The instructor asked the students to participate in the discussions in the Forum module. With the Diary module, students could address the objectives and organize their plans for the course. Reporting module presented students' learning performances in out-of school session. The module included data about frequencies of watching videos and number of forum messages, duration of the actions, and online test scores. The data gathered from the reporting module helped the instructor to organize the in-class activities.

In order to support students to use SRL strategies in the in-class sessions, students were given a worksheet at the beginning of the course. Activities in the worksheet are shown in Fig. 5. SRL strategies such as time management, help seeking, self-evaluation, organizing, rehearsing, and giving feedback (Pintrich, 2000; Zimmerman, 2008; Zumbrunn et al., 2011) were integrated into the in-class activities. 


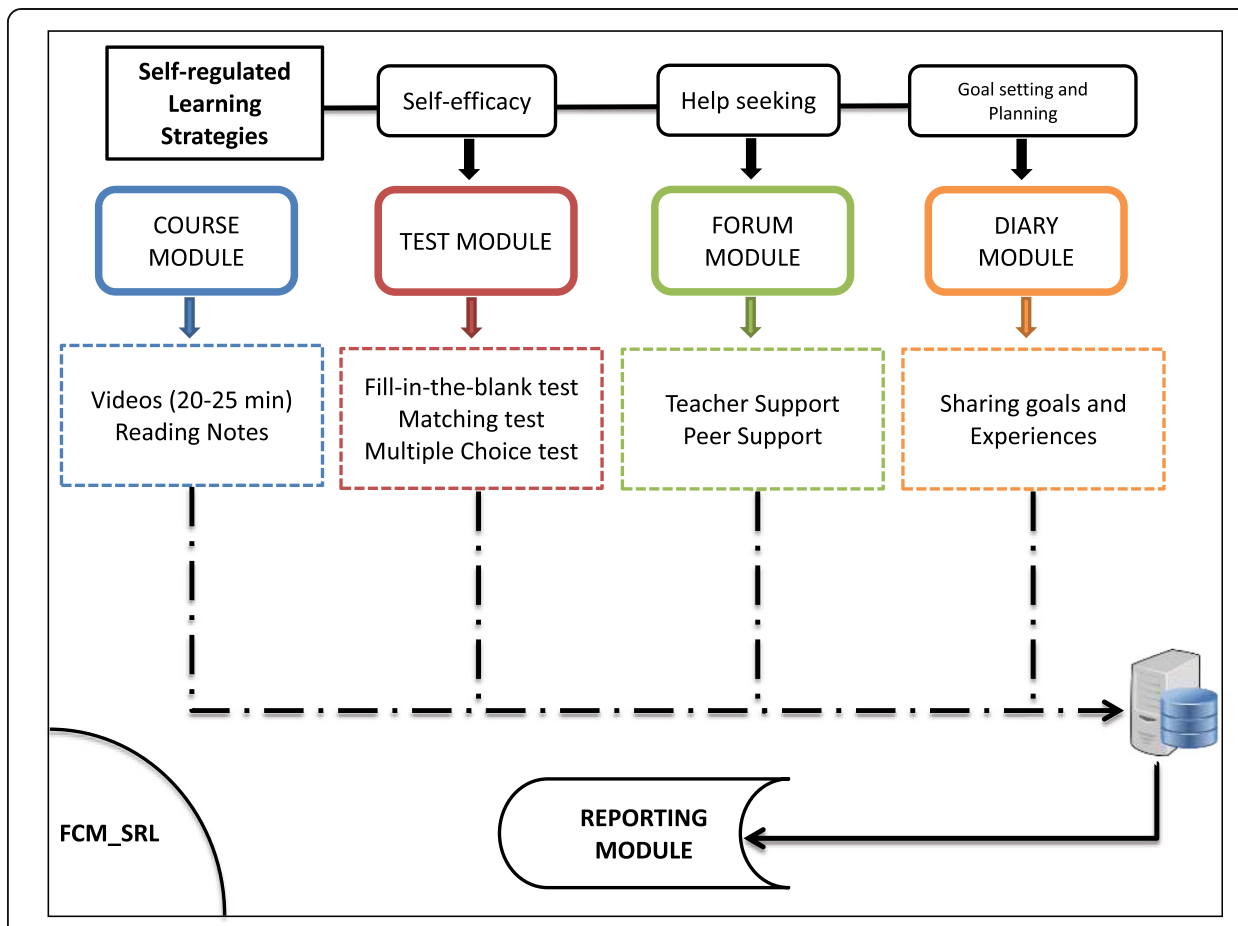

Fig. 4 Modules including SRL strategies in FCM_SRL

The students were separated into small groups according to their pre-test results. Each lesson had listening, reading, writing and speaking activities. Speaking activities were provided in the class with collaborative group activities which took place as conversations or dialogues including samples from real life.

During the listening activities, the students listened to the listening records and filled in the worksheets regarding the listening. In the writing activities, students wrote essays with regard to grammatical principles they learned in the online sessions. The SRL strategies during in-class sessions are as follows: During the work on the tasks, students were given a specific time for each activity (Time Management). They were expected to finish the activities during this time period. They prepared listening and reading activities together in the group and completed listening and reading activities individually. They were encouraged to get support from their peers and the instructor in writing and speaking activities (Help Seeking). Students were asked to perform the activities listening, reading, writing and speaking activities in a certain order (Organizing). The instructor provided feedback to the students considering the worksheet for missing or wrong answers. Discussions were allowed about the subjects that students mostly made mistakes (Feedback). At the end of the lessons, students were given the opportunity to evaluate their own learning performance (Self-evaluation). Self-reflection forms were given to the students to provide reasons about their own performances in listening, reading, writing and speaking activities. By doing so, students could compensate for their deficiencies or mistakes in the activities. 


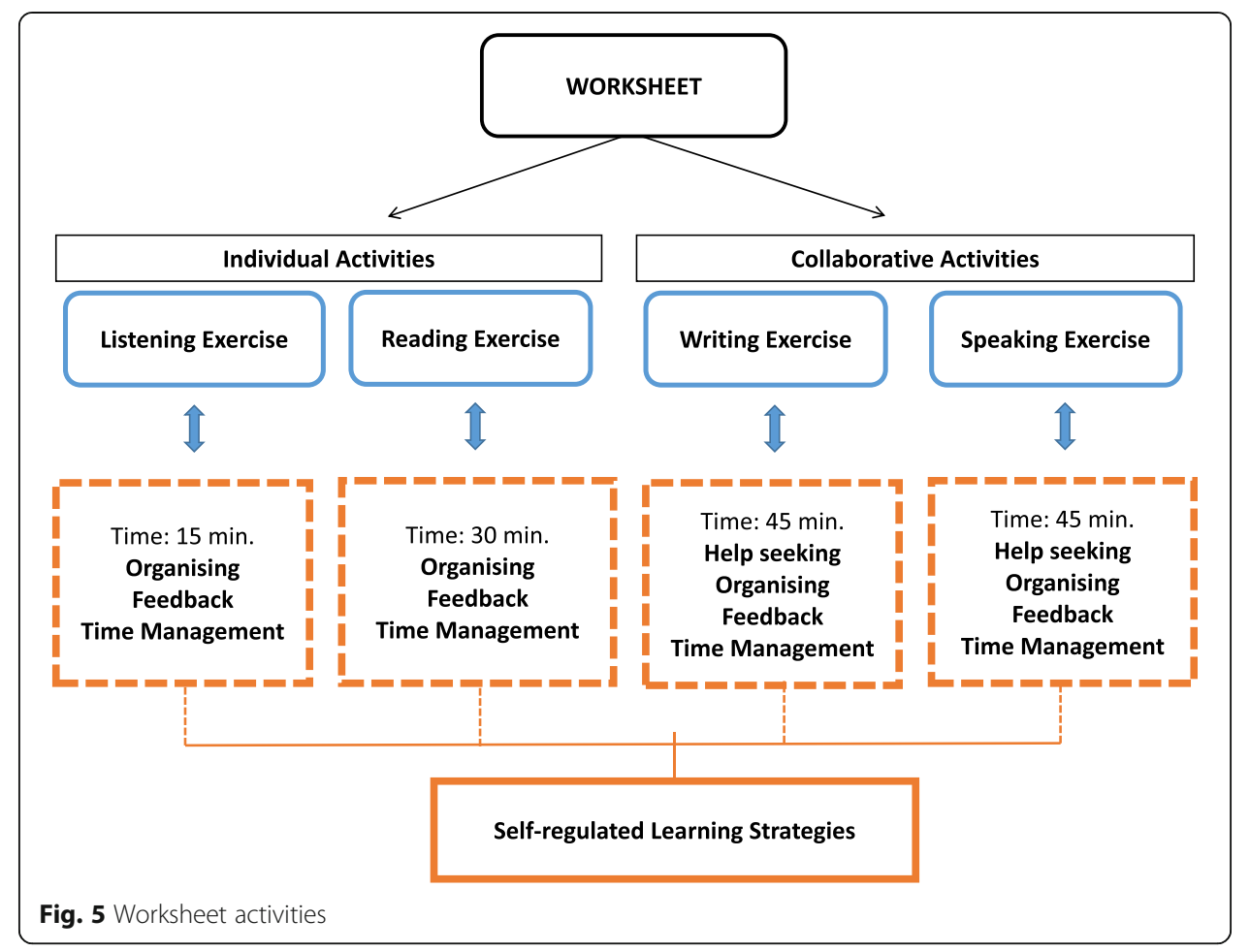

\section{Activities in control group}

Control Group students used the FCM_WEB platform to study online to construct knowledge for the in-class sessions. The Course module and the Test module were the same as those of EG. Students in this group provided self-assessment with the help of Test module after studying the course content (Online Test). During in-class sessions, they performed listening, reading, writing, and speaking activities. Listening and reading activities were similar to those of EG. In the writing activity, students wrote essays

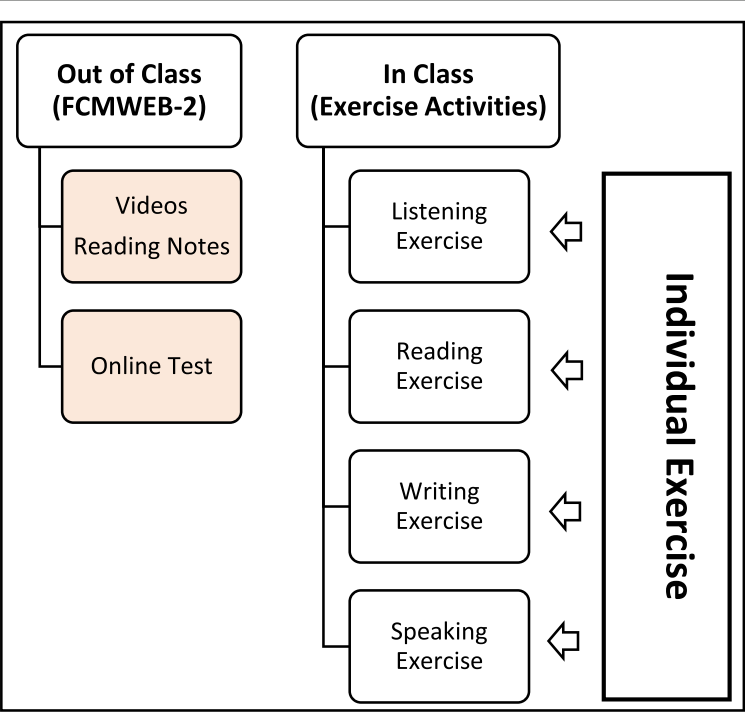

Fig. 6 Activities in Control group 
related to weekly topic. They worked together in speaking dialogues. The instructor generally provided corrective feedback to the students. Figure 6 shows the CG activities.

\section{Instruments}

An English Proficiency test, adapted from the Cambridge English Language Assessment, was used as the pre-test. An achievement test including grammar, listening, reading and writing sections was developed and implemented as post-test. The test was developed by the EFL instructor and it was validated through two experts' reviews. In the test, grammar test consisted of fill-in-the-blank, matching, multiple choice type questions. Listening test also included fill-in-the-blank type questions. The reading test consisted of multiple-choice tests. Writing test included writing essays that the students were asked to identify themselves and their family members in detail (physical properties, jobs, hobbies, skills etc.). Students were also required to state future plans and objectives in the essays. The instructor created a repository of dialogue questions for speaking tests and he used those for assessment. Each student was directed 10 questions for the speaking test.

\section{Data analysis}

The data satisfied all assumptions for t-test (the data is normally distributed in pre and post-test scores) and an independent t-test was conducted to analyze and compare the achievement scores of the groups considering the grammar, listening, reading, writing and speaking tests.

\section{Findings}

The pre-test and post-test scores have maximum possible scores of 100. Table 2 shows the descriptive scores from the pre-test. The results indicate that there is no significant difference between the EG and the CG students' pre-test scores.

The descriptive achievement post-test scores regarding EFL skills of EG and CG students were presented in Table 3.

Table 3 shows that the Listening test scores of the students in EG (34.44) were slightly higher than CG (27.08). Test average scores for Reading test in EG (70.28) were higher than those of CG students (49.92). In addition, writing test average scores of the students in EG (59) were higher than those of CG (44.83). While Speaking test scores in EG (56.4) were higher than CG (41.67), Grammar test results show that the average scores of EG (61. 20) were also higher than those of CG (44.17). Overall, the average score of EG (56. 41) was higher than that of CG (41.53).

The independent t-test results among two groups regarding post- test scores are shown in Table 4.

Table 2 Descriptive achievement pre-test statistics

\begin{tabular}{lllll}
\hline & Group & N & Mean & Sig. \\
\hline Pre-test & EG & 25 & 21.17 & .065 \\
& CG & 24 & 20.65 & \\
\hline
\end{tabular}


Table 3 Descriptive achievement post-test statistics

\begin{tabular}{lllll}
\hline EFL Skills & Group & N & Mean & SD \\
\hline Listening & EG & 25 & 34.44 & 15.869 \\
\multirow{2}{*}{ Reading } & CG & 24 & 27.08 & 16.513 \\
& EG & 25 & 70.28 & 23.167 \\
Writing & CG & 24 & 49.92 & 15.356 \\
& EG & 25 & 59.00 & 25.536 \\
Speaking & CG & 24 & 44.83 & 18.386 \\
& EG & 25 & 56.40 & 20.183 \\
Grammar & CG & 24 & 41.67 & 19.092 \\
& EG & 25 & 61.20 & 20.831 \\
Mean & CG & 24 & 44.17 & 12.218 \\
& EG & 25 & 56.26 & 16.118 \\
& CG & 24 & 41.53 & 12.414 \\
\hline
\end{tabular}

The t-test results indicate that a significant difference existed in favor of EG in speaking, reading, writing, grammar test scores. There was no significant difference in terms of listening test scores among the groups. However, a significant difference existed in the overall average scores in favor of EG.

\section{Discussion and conclusions}

In this study, student performances in EFL skills in FCM settings with and without SRL strategies were examined. Students in the experimental group where SRL strategies were used showed better performance in listening scores. This is in accord with previous studies that suggest FCM positively contribute to enhance EFL skills (Hao, 2016; Hung, 2015). However, there was no significant difference in terms of listening scores among the groups.

In two groups, the same listening activities with the same videos were conducted both in the out-of-class and in the in-class activities. Although time management and feedback strategies were implemented in EG, students of this group did not

Table $\mathbf{4}$ Independent samples post-tests statistics

\begin{tabular}{lllll}
\hline EFL Skills & Group & $\mathbf{t}$ & $\mathbf{d f}$ & Sig. \\
\hline Listening & EG & 1.590 & 47 & .118 \\
Reading & EG & & & $.001^{*}$ \\
Writing & CG & 3.611 & 47 & $.031^{*}$ \\
Speaking & EG & & & \\
Grammar & EG & 2.221 & 47 & $.012^{*}$ \\
Mean & GG & 2.623 & 47 & $.001^{*}$ \\
& EG & & & \\
$* p<.05$ & CG & 3.473 & 47 & $.001^{*}$ \\
\hline
\end{tabular}

${ }^{*} p<.05$ 
significantly outperform in listening and listening skills were improved in a certain level in both groups. This finding is consistent with the findings reported by Ahmad (2016) that students outperformed in FCM than traditional foreign language instruction in terms of listening skills.

In terms of reading skills, the results in this study showed that the reading test scores of EG were significantly higher than CG students. This may be due to the reading notes in the Course module. Using SRL strategies such as "goal setting and planning" and "feedback" can be considered as the factors positively influencing the reading scores of EG. In order to prepare students for the in-class activities, instructor shared his goals and plans at the beginning of the course and informed students about the way to carry out the course and the requirements in the learning process. The instructor also encouraged groups to check the worksheets and complete activities and supported students to engage in the reading activities. This finding is consistent with the findings reported by Huang and Hong (2016) in which FCM supported by interactive technology and feedback activities enhanced college students' reading skills.

FCM also positively influenced the writing skills as in other studies suggesting videoassisted interactive learning, collaborative learning, peer support, and corrective activities (Engin \& Donanci, 2016). Wu et al. (2017) implemented a pre- and post-test design and also found that EFL students' writing performance were developed the EFL students' in content and grammar issues. In the current study, the out-of school activities about writing at home supported students to take responsibility for the writing tasks in the in-class activities. Although EG and CG students came to the class after studying on the same content, FCM_SRL with the Forum module supported EG students to share and discuss on the writing essays. With this support, it may be considered that their writing skill might be more increased. Besides, in the in-class sessions, in the context of Help Seeking strategy, students in EG could get support from their peers about the required knowledge for writing.

In this study, one of the aims of the online system was to increase the interactions of student-student, student-instructor and student-content with regard to SRL strategies. In CG, students with low SRL struggled in taking responsibilities and completing the activities more than EG students. These findings concur with the previous work by Zhonggen and Guifang (2016) which revealed that FCM provided interactive learning environments for undergraduates to help them take their own learning responsibilities. This may be due to the fact that students in EG were allowed to monitor their own learning process with the worksheets and they could get support from their peers to empower their reading or writing skills. As suggested by the study of Zainuddin, Habiburrahim, Muluk, and Keumala (2019) forum and course modules enhanced student-student and student-content interactions in EG, helped students to coconstruct knowledge with each other.

According to $\mathrm{Wu}$ et al. (2017), interactive learning activities in FCM can contribute to improve speaking skills. Their study with undergraduate students showed that FCM improves students' speaking skills significantly by creating online learning communities at home and by practicing within authentic tasks during in-class sessions as well as by group discussions and group presentations. In this study, CG students acted in the speaking activities during in-class sessions and they were allowed to complete their deficiencies by asking questions directly to the instructor with in FCM_WEB online 
sessions. In EG, a discussion platform in the Forum module helped students at out-ofclass activities and they were given authentic tasks to collaborate with different speaking activities through worksheets. For example, in the activities of week 4, Group 2 created a conversation between a waiter and a customer in the restaurant by using simple present tense. Each group member had a role and provided dialogues in the speaking activity. It can be concluded that the modules designed for EG provided more interaction between students-instructor than those of CG when achieving the tasks in the in-class sessions. The interactions made EG students more active in the learning process that helped them enhance speaking skills. Similarly, Teng (2018) showed that shifting learners from passive to active learners in FCM can increase speaking skills.

Supporting to monitor the learning process also contributed the development of EFL skills in EG group. The instructor followed the performance of the students from FCM_SRL system and provided feedback for students who could not complete the activities. In the in-class sessions, students worked with writing and speaking activities in accordance with grammatical rules on the worksheet. For example, in week7, students in Group4 worked on affirmative, negative and interrogative action sentences with simple past tense and the instructor provided feedback on the worksheet in this process. Students were allowed to see and correct their mistakes within the worksheet by which the students in EG had the opportunity to be more active and to follow their performances.

FCM provides opportunities for students to interact with digital materials in out-of class sessions (Egbert et al., 2015). In this study, in out-of class sessions, students could repeatedly study on the course content with videos through Course module. Videos including listening, reading, writing and speaking activities with the guidance of grammatical principles somewhat contributed to the development of EFL skills in two groups. One can infer that the Course module in two groups increased access to the materials for developing the EFL skills. As addressed by other studies, the module supported the learning in two groups when they watched a video whenever and wherever they wished, and they could re-watch videos, or pause them to take notes (Bergmann \& Sams, 2012). Chuang et al. (2018) also reported that the online video course outside the class successfully enhanced students' learning motivation and self-paced learning skills in the English course.

The current study also concluded that using strategies to help students to actively engage in the activities in out of-class and in-class sessions may contribute enhancing basic EFL skills. Similarly, Hung (2015) found that FCM in which the students actively participated in the learning process improved the undergraduate students' EFL skills. However, in the current study, students with low SRL skills in CG encountered difficulties in performing the activities designed for out of-class and also for in-class sessions. This may be one of the reasons that the grammar test scores of the EG were significantly higher than those of the control group students. In this study, students were able to test their grammar knowledge with an online test in both groups. Students in EG assessed their performances in the subject with the online test and evaluated the activities with the Diary module. In the in-class sessions, they used self-assessment form in the worksheet. In the context of rehearsal strategy, the worksheet activities were prepared to cover the topics studied in the previous weeks. Accordingly, the students in EG easily worked on the previous week topics. In CG, students with low SRL skills 
encountered challenges in organizing information, transferring and monitoring their own learning process. When compared to CG, it is considered that the integrated strategies in EG had significant contribution, especially in organizing and monitoring the learning process.

In the out-of class sessions, reporting module was used by the instructor to monitor the students' behaviors and students shared their knowledge by assessing their learning process in the Diary module. Also, the instructor could encourage the students who did not perform activities at home by examining data from the diaries. This can be considered as a new kind of motivation provided by suggested SRL strategies. In the in-class sessions students were supported to organize the learning environment by working in a planned manner on authentic tasks with worksheet. They also evaluated their own learning process by filling out the self-evaluation form. Thus, this kind of systematic implementation of the strategies in in-class activities was also a contribution of this study to FCM practices.

This study also has a few limitations that should be noted. In the design of EG setting, the SRL strategies were integrated into the modules with regard to the affordances of the online tools of FCM. Besides, the instructor did not use English as a native language, which might have resulted in the low listening skills in the study. The size of the study subjects may also limit the generalization of the study findings. The experimental data was gathered from a group of undergraduate students who took an EFL course in through FCM. For generalization, a larger sample size would increase the sensitivity of the analysis, and future studies to investigate similar experimental designs with a more broad population are warranted. Also the instructional units about EFL course was specific. Thus, more sophisticated topics may offer using the FCM setting somewhat different. In addition, in two groups the instructor guided the students to complete their tasks by sharing their online reports. Although the same instructor was delivered the in-class and out-of-class sessions in two groups, he provided various feedback to the all relevant needs. So, it was difficult for the instructor to help in a particular level to any of the participant in the groups. Also the data in this study was collected with the items of a instructor developed test. For this reason, some other open-ended questions, may be more effective to acquire more comprehensive data related to the students' improvements in EFL skills.

Overall; the study confirmed for EFL class that well-designed in-class activities and effective learning management approaches are key components to the success of flipped classrooms (Chang \& Hwang, 2018). This is in accord with the study which found out that in EFL learning, the use of SRL strategies such as self-evaluation, organizing and transferring, searching for knowledge, help seeking and giving feedback positively contributed to enhance EFL skills (Bitchener, Young, \& Cameron, 2005). In this sense, the features of the online system used in FCM implementations become more crucial. Orooji and Taghiyareh (2015) also emphasized that the LMS used to monitor and update all information related to teaching-learning activities and provide instant feedback from their instructors is one of the key elements of the out-of-class sessions of FCM.

\section{Implications and future work}

In this study, the effect of FCM with and without SRL strategies was compared in terms of the development of EFL skills. The Forethought phase of SRL was integrated with 
strategies such as "goal-setting and planning", "self-efficacy" and "help seeking" at online sessions in out-of-school activities. For the Performance and Self-reflection phases, "rehearsal", "organizing", "time management" and "feedback" strategies were utilized in the in-class sessions. In the study, it was revealed that the students who were taught through the FCM integrated with SRL strategies had outperformed in reading, writing, speaking and grammar scores than those of traditional FCM. Surprisingly, there was no significant difference between the groups in terms of listening skill test scores.

Consequently, with an ultimate goal of EFL teaching through communication, the flipped classroom format can lead to more intercommunication for learning (Hosseini et al., 2020). When SRL strategies are integrated in the FCM through various tools, this can provide flexible access to learning resources and interactivity and support students in the learning process to manage their own learning process.

There are also some implications derived from this study. When implementing EFL course within FCM, the content about grammatical principles may be delivered in the online sessions with online support from instructor or peers. Students can practice grammar knowledge in various out-of-class activities. By this way, instructor can save time for implementing listening, reading, writing and speaking activities during in-class sessions by supporting their activities and providing feedback for students. Students can use the diaries in the out-of-school sessions in the direction of providing goal setting strategy. In addition, students can use the self-efficacy strategy by assessing their competence with the test module while benefiting from the help seeking strategy with the forum module. In the in-class sessions, students can work in various activities with the worksheet and organize the learning environment.

This study suggests that FCM_SRL (modules integrated with SRL strategies) can also be used for similar educational contexts and subject areas applying proper learning strategies. In future studies, the model may provide hints for implementing FCM strategies in the course design in different disciplines. In this study, providing avenues for more interaction during online lessons positively affected the outcomes in EFL courses. In this sense, further research is needed to determine the associations between interaction levels of FCM settings and the nature of EFL skills.

During the study, while we referred to some previous models to support SRL skills in-class environments, we encountered with some challenges in determining SRL indicators for the out-of class sessions. In future works, learning analytics techniques can be used for online sessions to provide more meaningful data for identifying SRL of students. Worksheets specially prepared for collaborative groups can be shared with students before the lesson and time can be used more efficiently for both groups.

Consequently, the contribution of this study is implementing FCM in EFL courses is two-fold; from the teaching techniques of EFL skills such as listening, reading, writing, and speaking and also from evaluating the developments of EFL skills. To conclude, the study suggests that to improve EFL skills, associating SRL strategies and FCM affordances through the nature of EFL course can be a solution for both teaching and evaluating. We hope that this study sheds a light on implementing various adoptions of FCM and may help educators in the instructional design and teaching side of EFL courses. 


\section{Appendix 1}

Table 5 FCM_SRL Diary Module Questions

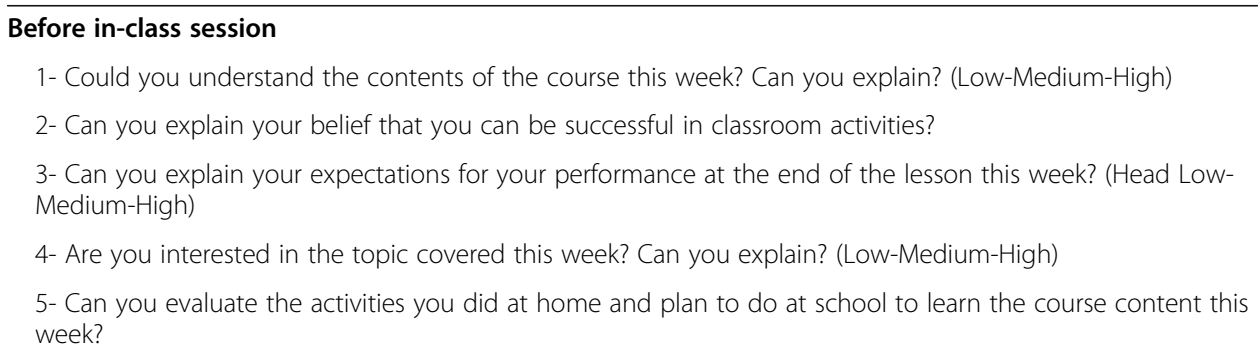

\section{Appendix 2}

Table 6 FCM_SRL Self-reflection Form Questions

After in-class session
1-Can you evaluate your performance in your listening activities? (Low-Medium-High)
2-Can you evaluate your performance in your reading activities? (Low-Medium-High)
3-Can you evaluate your performance in your writing activities? (Low-Medium-High)
4-Can you evaluate your performance in your speaking activities? (Low-Medium-High)
5- Explain the shortcomings you see in yourself regarding your performance this week?
6-What do you intend to do to increase your performance next week?

Appendix 3

Table 7 Experimental group activity example in the 3rd week

\begin{tabular}{|c|c|}
\hline Subject & Simple Present Tense \\
\hline $\begin{array}{l}\text { Listening } \\
\text { activities }\end{array}$ & $\begin{array}{l}\text { The audio recording of "the seven wonders of the world" was listened to the students. The } \\
\text { text version of the voice recording was available on the worksheet. However, some words } \\
\text { were omitted from the text. The students tried to fill in the blank areas by listening to the } \\
\text { audio recording. Students were given } 10 \text { min. After the students completed their tasks, the } \\
\text { worksheets were checked, feedback was given and the correct answers were shared with the } \\
\text { students. }\end{array}$ \\
\hline $\begin{array}{l}\text { Reading } \\
\text { activities }\end{array}$ & $\begin{array}{l}\text { Students read the text on the worksheet that gave detailed information about "the seven } \\
\text { wonders of the world" }(15 \mathrm{~min} \text {.). Then, they answered multiple choice and blank-filled ques- } \\
\text { tions about the text }(15 \mathrm{~min} \text {.). At the end of the activity, the instructor checked the students' } \\
\text { worksheets and gave feedback. He discussed his answers with the students. }\end{array}$ \\
\hline $\begin{array}{l}\text { Writing } \\
\text { activities }\end{array}$ & $\begin{array}{l}\text { The students prepared a simple present tense speech activity with their group members. Each } \\
\text { student was required to have at least } 3 \text { dialogues. The groups determined the subject of the } \\
\text { dialogues themselves. The instructor encouraged in-group collaboration and gave frequent } \\
\text { feedback to his students ( } 45 \text { min.). }\end{array}$ \\
\hline $\begin{array}{l}\text { Speaking } \\
\text { activities }\end{array}$ & $\begin{array}{l}\text { The groups presented the dialogues they prepared in the writing activity to other groups. } \\
\text { Other groups evaluated students who made presentations ( } 45 \mathrm{~min} \text {.). }\end{array}$ \\
\hline
\end{tabular}

At the end of the lesson, students were asked to evaluate their in-class performances on a self-reflection form. Students were expected to make evaluations about whether their performance would have an impact on their studies for the next week 


\section{Abbreviations}

EFL: English as Foreign Language; FCM: Flipped Classroom Model; SRL: Self-Regulated Learning

\section{Acknowledgements}

We would like to thank to the administrators of the department.

\section{Authors' contributions}

Ünal Çakıroğlu: Conceptualization, Writing - Review \& Editing, Supervision. Mücahit Öztürk: Formal analysis, Investigation, Methodology, Writing - Original draft preparation. The author(s) read and approved the final manuscript.

\section{Funding}

No funding exist.

Availability of data and materials

Data will not be shared.

\section{Competing interests}

No competing interests exist.

\section{Author details}

${ }^{1}$ Department of Computer Education and Instructional Technology, Faculty of Education, Aksaray University, Aksaray, Turkey. ${ }^{2}$ Department of Computer Education and Instructional Technology, Fatih Faculty of Education, Trabzon University, Söğütlü, Akçaabat, 61335 Trabzon, Turkey.

Received: 9 September 2020 Accepted: 11 January 2021

Published online: 08 February 2021

\section{References}

Adnan, M. (2017). Perceptions of senior-year ELT students for flipped classroom: A materials development course. Computer Assisted Language Learning, 30(3-4), 204-222.

Ahmad, S. Z. (2016). The flipped classroom model to develop Egyptian EFL students' listening comprehension. English Language Teaching, 9(9), 166.

Al-Samarraie, H., Shamsuddin, A., \& Alzahrani, A. I. (2019). A flipped classroom model in higher education: A review of the evidence across disciplines. Educational Technology Research and Development, 68, 1017-1051.

Amiryousefi, M. (2019). The incorporation of flipped learning into conventional classes to enhance EFL learners' L2 speaking, L2 listening, and engagement. Innovation in Language Learning and Teaching, 13(2), 147-161.

Artino, A. R., \& Stephens, J. M. (2009). Academic motivation and self-regulation: A comparative analysis of undergraduate and graduate students learning online. The Internet and Higher Education, 12(3), 146-151.

Bergmann, J., \& Sams, A. (2012). Flip your classroom: Reach every student in every class every day. Eugene, OR: International Society for Technology in Education.

Bitchener, J., Young, S., \& Cameron, D. (2005). The effect of different types of corrective feedback on ESL student writing. Journal of Second Language Writing, 14(3), 191-205.

Blau, l., \& Shamir-Inbal, T. (2017). Re-designed flipped learning model in an academic course: The role of co-creation and coregulation. Computers \& Education, 115, 6981.

Cabı, E. (2018). The impact of the flipped classroom model on students' academic achievement. The International Review of Research in Open and Distance Learning, 19(3), 203-221.

Çakıroğlu, Ü., \& Öztürk, M. (2017). Flipped classroom with problem based activities: Exploring self-regulated learning in a programming language course. Journal of Educational Technology \& Society, 20(1), 337-349.

Chang, S. C., \& Hwang, G. J. (2018). Impacts of an augmented reality-based flipped learning guiding approach on students' scientific project performance and perceptions. Computers \& Education, 125, 226-239.

Chen Hsieh, J., Huang, Y. M., \& Wu, W. C. (2017). Technological acceptance of LINE in flipped EFL oral training. Computers in Human Behavior, 70, 178-190.

Chen Hsieh, J., Wu, W. C., \& Marek, M. W. (2017). Using the flipped classroom to enhance EFL learning. Computer Assisted Language Learning, 30(1-2), 1-21.

Cho, M. H. (2004). The effects of design strategies for promoting students' self-regulated learning skills on students' self-regulation and achievements in online learning environments. In 27. Chicago, IL: Association for Educational Communications and Technology.

Chuang, H. H., Weng, C. Y., \& Chen, C. H. (2018). Which students benefit most from a flipped classroom approach to language learning? British Journal of Educational Technology, 49(1), 56-68.

Egbert, J., Herman, D., \& Lee, H. (2015). Flipped instruction in English language teacher education: A design-based study in a complex, open-ended learning environment. Tesl-Ej, 19(2), n2.

Engin, M., \& Donanci, S. (2016). Instructional videos as part of a 'flipped'approach in academic writing. Learning and Teaching in Higher Education: Gulf Perspectives, 13(1), 1-8.

Evseeva, A., \& Solozhenko, A. (2015). Use of flipped classroom technology in language learning. Procedia-Social and Behavioral Sciences, 206, 205-209.

Ferreira, P. C., Simão, A. V., \& da Silva, A. L. (2017). How and with what accuracy do children report self-regulated learning in contemporary EFL instructional settings? European Journal of Psychology of Education, 32(4), 589-615.

Hao, Y. (2016). Middle school students' flipped learning readiness in foreign language classrooms: Exploring its relationship with personal characteristics and individual circumstances. Computers in Human Behavior, 59, 295-303. 
Hosseini, H. M., Ejtehadi, A., \& Hosseini, M. M. (2020). Flipping microlearning-based EFL classroom to enhance learners' selfregulation. Language Teaching Research Quarterly, 20, 43-59.

Huang, Y. N., \& Hong, Z. R. (2016). The effects of a flipped English classroom intervention on students' information and communication technology and English reading comprehension. Educational Technology Research and Development, 64(2), 175-193.

Hung, H. T. (2015). Flipping the classroom for English language learners to foster active learning. Computer Assisted Language Learning, 28(1), 81-96.

Kostaris, C., Sergis, S., Sampson, D. G., Giannakos, M. N., \& Pelliccione, L. (2017). Investigating the potential of the flipped classroom model in K-12 ICT teaching and learning: An action research study. Educational Technology \& Society, 20(1), $261-273$.

Lai, C. L., \& Hwang, G. J. (2016). A self-regulated flipped classroom approach to improving students' learning performance in a mathematics course. Computers \& Education, 100, 126-140.

Leatherman, J. L., \& Cleveland, L. M. (2020). Student exam performance in flipped classroom sections is similar to that in active learning sections, and satisfaction with the flipped classroom hinges on attitudes toward learning from videos. Journal of Biological Education, 54(3), 328-344.

Lee, G., \& Wallace, A. (2018). Flipped learning in the English as a foreign language classroom: Outcomes and perceptions. Tesol Quarterly, 52(1), 62-84.

Lin, C. J., \& Hwang, G. J. (2018). A learning analytics approach to investigating factors affecting EFL students' oral performance in a flipped classroom. Journal of Educational Technology \& Society, 21(2), 205-219.

Liu, C., Sands-Meyer, S., \& Audran, J. (2019). The effectiveness of the student response system (SRS) in English grammar learning in a flipped English as a foreign language (EFL) class. Interactive Learning Environments, 27(8), 1178-1191.

Morshedian, M., Hemmati, F., \& Sotoudehnama, E. (2017). Training EFL learners in self-regulation of reading: Implementing an SRL model. Reading \& Writing Quarterly, 33(3), 290-303.

$\mathrm{Ng}, \mathrm{E}$. M. (2018). Integrating self-regulation principles with flipped classroom pedagogy for first year university students. Computers \& Education, 126, 65-74.

Orooji, F., \& Taghiyareh, F. (2015). Supporting participants in web-based collaborative learning activities from a holistic point of view: a tale of seven online and blended courses. Journal of Computers in Education, 2(2), 183-210.

Panadero, E., \& Alonso-Tapia, J. (2014). How do students self-regulate? Review of Zimmerman's cyclical model of selfregulated learning. Anales de Psicologia/Annals of Psychology, 30(2), 450-462.

Pintrich, P. R. (2000). The role of goal orientation in self-regulated learning.

Rahman, A. A., Aris, B., Mohamed, H., \& Zaid, N. M. (2014). The influences of flipped classroom: A meta analysis. Kuala Lumpur: In IEEE 6th Conference on Engineering Education (ICEED).

Rasheed, R. A., Kamsin, A., Abdullah, N. A., Kakudi, H. A., Ali, A. S., Musa, A. S., \& Yahaya, A. S. (2020). Self-regulated learning in flipped classrooms: A systematic literature review. International Journal of Information and Education Technology, 10(11), 848-853.

Roohani, A., \& Asiabani, S. (2015). Effects of self-regulated strategy development on EFL learners' reading comprehension and metacognition. GEMA Online ${ }^{\oplus}$ Journal of Lanquage Studies, 15(3), 31-49

Shih, H. C. J., \& Huang, S. H. C. (2020). College students' metacognitive strategy use in an EFL flipped classroom. Computer Assisted Language Learning, 33(7), 755-784.

Sun, Z., Xie, K., \& Anderman, L. H. (2018). The role of self-regulated learning in students' success in flipped undergraduate math courses. The Internet and Higher Education, 36, 41-53.

Teng, M. F. (2018). Flip your classroom to improve EFL students' speaking skills. In Innovations in flipping the language classroom, (pp. 113-122). Singapore: Springer.

Turan, Z., \& Akdag-Cimen, B. (2020). Flipped classroom in English language teaching: a systematic review. Computer Assisted Language Learning, 33(5-6), 590-606.

van Alten, D. C., Phielix, C., Janssen, J., \& Kester, L. (2020). Self-regulated learning support in flipped learning videos enhances learning outcomes. Computers \& Education, 158, 1-16.

Wang, F. H. (2017). An exploration of online behaviour engagement and achievement in flipped classroom supported by learning management system. Computers \& Education, 114, 79-91.

Wang, F. H. (2019). On prediction of online behaviors and achievement using self-regulated learning awareness in flipped classrooms. International Journal of Information and Education Technology, 9(12), 874-879.

Wanner, T., \& Palmer, E. (2015). Personalising learning: Exploring student and teacher perceptions about flexible learning and assessment in a flipped university course. Computers \& Education, 88, 354-369.

Williamson, G. (2015). Self-regulated learning: An overview of metacognition, motivation and behavior. Journal of Initial Teacher Inquiry, 1, 25-27.

Wu, W. C. V., Hsieh, J. S. C., \& Yang, J. C. (2017). Creating an online learning community in a flipped classroom to enhance EFL learners' oral proficiency. Journal of Educational Technology \& Society, 20(2), 142-157.

Zainuddin, Z., Habiburrahim, H., Muluk, S., \& Keumala, C. M. (2019). How do students become self-directed learners in the EFL flipped-class pedagogy? A study in higher education. Indonesian Journal of Applied Linguistics, 8, 678-690. https://doi.org/ 10.17509/ijal.v8i3.15270.

Zheng, B., Ward, A., \& Stanulis, R. (2020). Self-regulated learning in a competency-based and flipped learning environment: Learning strategies across achievement levels and years. Medical Education Online, 25(1), 1686949.

Zhonggen, Y., \& Guifang, W. (2016). Academic achievements and satisfaction of the clicker-aided flipped business English writing class. Educational Technology \& Society, 19(2), 298-313.

Zimmerman, B. J. (1990). Self-regulated learning and academic achievement: An overview. Educational Psychologist, 25(1), 3-17.

Zimmerman, B. J. (1998). Developing self-fulfilling cycles of academic regulation: An analysis of exemplary instructional models. In D. H. Schunk, \& B. J. Zimmerman (Eds.), Self-regulated learning: From teaching to self-reflective practice, (pp. 119). New York: Guilford Press.

Zimmerman, B. J. (2008). Investigating self-regulation and motivation: Historical background, methodological developments, and future prospects. American Educational Research Journal, 45(1), 166-183. 
Zou, D. (2020). Gamified flipped EFL classroom for primary education: Student and teacher perceptions. Journal of Computers in Education, 7(2), 223-228.

Zou, D., Luo, S., Xie, H., \& Hwang, G. J. (2020). A systematic review of research on flipped language classrooms: Theoretical foundations, learning activities, tools, research topics and findings. Computer Assisted Language Learning, 1-27.

Zumbrunn, S., Tadlock, J., \& Roberts, E. D. (2011). Encouraging self-regulated learning in the classroom: A review of the literature. Metropolitan Educational Research Consortium (MERC).

\section{Publisher's Note}

Springer Nature remains neutral with regard to jurisdictional claims in published maps and institutional affiliations.

Submit your manuscript to a SpringerOpen ${ }^{\odot}$ journal and benefit from:

- Convenient online submission

- Rigorous peer review

Open access: articles freely available online

- High visibility within the field

- Retaining the copyright to your article

Submit your next manuscript at $\boldsymbol{\nabla}$ springeropen.com 